\title{
The Role of Instructional Supervision on Students’' Academic Performance in Injibara Administrative Town General Primary Schools
}

\author{
Agegnehu Alene Demozie \\ Lecturer, Department of Educational Planning and Management, College of Education and Behavioral sciences, \\ Injibara University, Ethiopia
}

\begin{abstract}
The purpose of the study was to assess the role of instructional supervision on students' academic performance in Injibara administrative town general primary schools. This study would provide to some insight to improve the role of instructional supervision on students' academic performance in Injibara administrative town general primary schools. The study was mainly focused and delaminated on the role of instructional supervision on students' academic performance in Injibara administrative town general primary schools. Different literatures related to the issue were used to strength the study. Descriptive survey research design was used and data was primarily collected through questionnaire interview and document analysis from primary schools. Out of 7 government primary schools, 5 schools were selected through simple random sampling technique. From these schools 107 teachers were selected through stratified random sampling technique and supervisors and principals of sample schools were taken by using comprehensive sampling technique. The findings of the study showed that the role of instructional supervision practice reported mean was lower than expected results and as the result the students achievements was above average and nearest to the expected mean. Negative and insignificant relationship was observed between school supervisors' practices and students' academic achievement in Injibara administrative town general primary schools (-.029). The conclusion drawn from this study showed that the school supervisors' practice was lower than expected mean but the result of the students' achievements was at average level.
\end{abstract}

Keywords: Supervision, Instructional supervision, Students’ performance, General primary-school

DOI: $10.7176 / \mathrm{JEP} / 12-19-03$

Publication date:July $31^{\text {st }} 2021$

\section{Introduction}

Education is the main sources of all developments and essential for every country in the world. As in many other developing countries, in our country- Ethiopia, education has been given great attention for it is the basic way of economic growth and all-rounded development of the society. This requires the effectiveness and commitment of stakeholders particularly teachers, school leaders and management, (Aggarwl, 1985).

This is clearly explained in Ethiopia Education Policy and Training,(1994). Education is a process by which man transmits his experiences, new findings, and values accumulated over the years, in his struggle for survival and development, through generations. Education enables individuals and society to make all-rounded participation in the development process by acquiring knowledge, ability, skills and attitudes. One of the aims of education is to strengthen the individuals and society's problem-solving capacity, ability and culture starting from basic education and at all levels. The research work of Ikegbusi\& Iheanacho, (2016) also strengthens the above idea by stating, Education is also the bedrock of any nations' socio-economic, cultural, religious and political development.

The Education and Training Policy (ETP) formulated in 1994 set high standards for Educational Organization and Management and teachers describing a new approach to education to improve quality of education at the heart of this new approach, the promotion of active learning, problem solving, and student centered teaching methods are emphasized. The policy clearly indicated that emphasis should be given to upgrading and updating both pre-service and in-service teachers. Recognizing this issue, the Government has introduced different programs including the Education Sector Development Programs (ESDPs I-V) in which General Education Quality Improvement Package(GEQIP) becomes an integral part of ESDP IV government took different actions in different areas like in access, equity and equality, enrollment, quality etc. even though most of them are at good achievement quality of education and students' achievements are still not at good achievement. This requires the effectiveness and commitment of all stakeholders particularly teachers, schools leaders and managements. According to Nwogbo and Okeke, (2010) this can be achieved through a disciplined and committed teachers. To ensure that teachers are highly disciplined and their high productivity achieved in the education sector, this apart from staff development will also include strengthening schools' instructional supervision to ensure that teachers high productivity and work commitment is guaranteed and enhanced (Ikegbusi, 2014). 
So schools must improve their basic functions of teaching and learning process that aims at helping and empowering all students to raise their broad outcomes through instructional improvement, administration, instruction and supervision are responsible for the highest performance of students in schools. Furthermore, the Ministry of Education (MoE, 2010), in its Education Sector Development Program (ESDP IV), has stressed the necessity of teacher supervision and support as a strategy to insure quality of teaching and learning.

According to Ogba and Igu, (2014) supervision has been identified as one of the approaches to teacher effectiveness. This calls for supervision of instructional procedure in secondary schools. Supervision according to Modebelu, (2008) is a process of assisting, directing, stimulating and motivating teachers to enhance teaching and learning process in educational institution.

In addition to this, $($ Ogbo,2015) defined supervision as the maximum development of the teachers into the most professionally efficient and effective person she/he is capable of becoming. This definition recognizes that a teacher has potentials that needed help guidance and directing. Walker, (2016) and Clark, (2015) on the other hand see supervision as a task of improving instruction through regular monitoring and in-service education of teachers.

Supervision in the school system mainly focuses on the whole school improvement and quality of education given to the students. In the light of this, (MoE,2002) stated supervision as the process in which supervisors provide professional support for the school principals and teachers to strengthen the teaching and learning process. Similarly, according to Trait discussed in the Association for the Development of Education in Africa (ADEA, 1998) supervision is taken as the process in which supervisors visit schools to work with the teachers and school administrators to ascertain the quality of teaching and administration. Thus, adequate support and effective supervisory activities are very crucial for schools to enhance the teaching learning process.

"In addition to this, according to MOE, (1994) school-based supervisors and external supervisors are responsible to carry out educational supervision. In this regard, the Woreda, Zonal, Regional and Central supervisory educators are structured under external supervisors. While, school principals, vice principals, unit leaders and department heads are categorized under the actors of school-based (internal) supervision.

Internal supervision is carried out by the school administrators (headmaster/assistant headmaster or principal/vice principal), while government and delegated agents conduct the external supervision. Not only is this, in the recent research there is comparison, the effectiveness of the two modes in improving teachers' teaching skills. According to Modebelu,(2008) and Walker, (2016) were of the opinion that external supervision is more effective in promoting teacher instructional effectiveness in schools. But Eya and Leonard, (2012), postulate that internal supervision is more conversant, their reasons being that it helps teachers to be dedicated to their duties and helps the less effective and inexperienced teachers to improve their teaching skill.

Since these internal supervisors are within the schools and some of them are teachers, they are responsible to assist teachers closely and continuously for the improvement of the instruction. Because, teaching - learning process is a day- to-day activity, which is carried out by teachers in schools. The problems that teachers encountered while they are teaching can be solved through internal supervisors.

In order to improve teacher's performance and students' achievement, improvement of instructional supervision plays a crucial role. Researchers such as Sergiovanni, T. J., \&Starratt, R. J. (2002) believed that instructional supervision has the potential to improve class-room practices and contribute to student success through professional growth and improvement of teachers.

International Institute of Planning, (2001) indicated that school leaders in general and principals in particular have vital responsibilities in promoting teachers active learning in such a way that allocating resources, initiating teachers to exercise and try out peer observation, peer coaching and arranging staff meeting. However, there are inadequate supervisory services in the area of instructional implementation in the class room, in problem solving, in conducting and implementing action research, in adapting, implementing and evaluating curriculum.

The findings of different research conducted on the practice of instructional supervision in primary schools of different Regions and Zones of our country have shown that, there was a lack of awareness on utilizing various supervisory options, a lack of relevant continuous trainings for department heads and senior teachers who are supposed to carry out supervisory activities at school level, and also there $\mathrm{s}$ inadequate classroom observation to monitor teachers $^{\text {ee }}$ instructional improvement (Chanyalew, 2005; Getachew, 2001; Million, 2010).

In addition to these, less attention was given to internal instructional supervision by both internal supervisors and teachers. Due to this reason this study was mainly focused on the assessing the contribution of instructional supervision in improving teachers' teaching skills in Injibara Administrative City of government primary schools.

\section{REVIEW OF RELATED LITERATURE}

\subsection{Concept of Supervision}

The concept of supervision can be traced back to the origin of public education, a period when young states used 
it establish a common culture and language (De Grauwe, 2007). During this time, supervision gradually emerged as a practice that is distinct in connection with professional, cultural, academic and institutional dynamics which have for a long time generated the schooling agenda. Much of school supervision history describes as a series of unrelated and disjointed events (Glanz, 1994). The concept of supervision was originally introduced in order to improve the teaching and learning situation through professional growth and development of the teachers and educators (Glanz, 1994).

Supervision is meant to improve the performance in work in any context. It should be used to enhance effective methods of teaching as well as contribute to professional growth and development of the teachers (Blumberg \& Weimer, 2008). The concept of supervision has been defined differently by various scholars (Olembo et al., 1992). From an educational view point, Zepeda (2007) conceptualizes supervision as process that is ongoing and which is meant to improve instructions and professional development. Waweru (2004) defines supervision as "the process of working with and through others in a more humane understanding to achieve to the greatest extent possible a quality education for all students".

On the other hand, Olembo et al. (1992) define supervision as that phase or dimension in education administration that is associated with the improvement of instructional effectiveness. The key denominator among the various definitions and views on supervision is that it is aimed at developing better quality of education. According to (Glickman, 2010) supervision is "the school function that improves instruction through direct assistance to teachers, curriculum development, in-service training, group development and action research".

The primary goal of school supervisory practices is improving instruction of teaching and learning (Archibong, 2010). Opportunities arising from supervision make it possible for the teachers to be moulded through a deeper study of classroom interactions and instructional activities in order to perform teaching duties in accordance with their professional code of conduct. Supervisors ought to help the personnel being supervised to realize their potential in the course of conducting supervisory exercise (Jahanian \& Ebrahimi, 2013). It is important the supervisor monitors the teachers' work, queries the teachers on why they use certain teaching methods and later provide them with information on best practices in teaching which would hence improve the educators in their teaching practice. The practice of supervision offers an opportunity to both the supervisors and teachers to work harmoniously in improving student learning (Aseltine, Faryniarz, \& Rigazio-Digilio, 2006). Inadequate school supervision has inimical implication on the students' output academically as well as challenges to the realization of educational objective (Usman, 2015). Consequently, it would be prudent to ensure that wide ranging instructional supervisory techniques are adopted in order to achieve quantitative and qualitative delivery of service by the teachers (Usman, 2015). The concept of supervision is two-fold where on one hand it serves to improve the professional growth and development of the teachers while on the other it is tied to improving the students' performance. It can thus be premised that supervision function is a manifestation of instructional leadership (Okumbe, 2006).

Instructional supervision and process aids in the improvement of academic performance among students. This is premised on the fact that instructional supervision enhances teaching and learning through proper planning and guidance. Furthermore, Okendu (2012) asserts that through supervision of instruction, new QQ1ways are devised that aim to improve teachers professionally and as a result help them to unleash their creative potential and consequently ensure instructional process is well articulated and improved.

\subsection{Principles of Instructional Supervision}

There are a number of general principles, which guide the practice of supervision as well as discussions about it. Educational supervision has been defined as 'The provision of guidance and feedback on matters of personal, professional and educational development in the context of a trainee's experience of providing safe and appropriate patient care' (Pajaak, 2000). All teachers are now required to have educational supervision across their whole training period, from qualification to specialist certification (Sergrivanni, 2007).In addition to this the necessity of educational supervision is not only for trainers but also it is important and essential for new and experienced teachers. Particularly instructional supervision processes must meet the unique needs of all teachers being supervised. From the beginning teacher to the well experienced teacher, instructional supervision must provide a variety of opportunities for each teacher (Nolan and Hoover, 2004). However, the standards and procedures expected of the first-year teachers is exactly the same as experienced teachers the moment the new teachers enter their classroom. (Danielson and McGeal, 2000. Nolan and Hoover, 2005) identified seven essential skills of classroom-based supervision. These skills include:

1. Builds trust and positive communication.

2. Uncover espoused platforms and platforms in use.

3. Encourage continuous reflection and inquiry into teaching.

4. Collects systematic data.

5. Interpret and use the data. 
6. Conference

7. Foster a school wide climate that values community, collaboration and continuous growth.

As indicated in the Manual for Educational Supervision in Ethiopia (MOE, 1987 E.C.) There are some basic principles of supervision. These are:

Supervision is cooperation work; the main purposes of supervisions are professional and curriculum development for creating better learning situation for students. This demands the cooperative work of senior teachers, department heads, unit leaders, a vice directors, directors and administrators at the school level. At the various education offices, there are also supervisors, education program officers, bureau heads and administrators cooperatively participate in supervision. The efficiency and effectiveness of supervision depends on the cooperative effort put together

Supervision is creative of change; This principle suggested that supervision should seek latest talents, provide opportunity for the exercise of originality and for the development of unique contributions. Supervisors should help teachers to be creative and innovative in their methodology of teaching.

Supervision is free from force; This implies that supervision as a cooperative and creative work, it has to be democratic where every member has the liberty to try and express her/his ideas with freedom. The institutional hierarchy should exercise authority for favorable end result. It should not be used to show superiority.

\subsection{Approaches to Supervision}

Various approaches have been identified by scholars as being used by head teachers in their supervisory functions with the most common being directive approach, collaborative approach and non-directive approach (Glickman, 2010).

\subsubsection{Directive Approach}

In a directive approach, supervisors are of the view that the practice of teaching is a composition of technical skills that are standardized and known competencies which teachers must possess to be effective in their instructional practices (Glickman, 2010). In this approach, the roles of a supervisor are to assess, model and direct competencies. Supervisors using directive approach have their own information needs and know how it will be collected. Such supervisors direct the educators on the appropriate action plans to be taken as well as the best teaching methods. The baseline information gathered from classroom observation among others is used for setting improvement standards by directive supervisor. A supervisor using the directive model influences the trainer by offering suggestions and opinions that he/she perceives as being needed by the teacher (Copeland, 1982). The primary objective of directive supervisory model is offering the teacher useful and immediate advice to handle difficulties associated with instructional process. Directive model of supervision is often used when there is a new teacher and requires more directive guidance or when a teacher has difficulties in instructional process and requires close guidance/monitoring. This is best applied to novice teachers who are in need of more guidance and direction. By assuming the directive approach of supervision the supervisor takes the direct ownership emanating from the problems as well as the corresponding solutions. The supervisor's role is very active and prescriptive. In most cases, contact is initiated by the supervisor who directs the focus in all the subsequent meetings. In this approach, the supervisor uses such behaviors as directing, standardizing and reinforcing. Since the teacher receives guidance from the supervisor, he/she would be able to apply the best teaching and learning practices that are aimed at enhancing the student performance.

\subsubsection{Collaborative Approach}

In a collaborative approach, supervisors present teaching as a problem solving situation. In this approach, two or more individuals pose a challenge, try and implement the teaching strategies that are considered to be relevant (Glickman, 2010). The supervisor in this approach guides the process of problem solving while keeping teachers focused on their shared problems. The supervisors and the teachers have an agreement that is mutually binding regarding the criteria, processes and structures for subsequent instructional improvement. The plan of action is negotiated between the teacher and the supervisor. The views of both the supervisor and the teacher are included in the final action plan for instructional improvement. If any of the parties is dissatisfied with the action plan, they stand to reject it and negotiate again till they agree. However, the parties in a collaborative approach have to accept idea modifications and not necessarily taking hard stands (Glickman, 2010).

Glickman (2010) states that "collaborative models advocate that the supervisor is equal with the teacher, presenting, interacting, and contracting on mutually planned changes". The supervisor's role in this approach is guiding the problem solving process while remaining an active participant in the interaction. Collaborative approach of instructional supervision provides opportunities for the teachers to share their perceptions as well as offering likely alternatives for future action. Ibrahim (2013) in a study of student teachers in United Arab Emirates established that $83.3 \%$ of them preferred the use of collaborative approach. The collaborative approach to instructional supervision is interactive in nature. The parties plan the process collaboratively. This way it creates rapport and hence both supervisor and the teacher have ownership of the entire process. It is nonevaluative in nature but aimed at strengthening professional relationship between the supervisor and supervisee. 


\subsubsection{Non-Directive Approach}

This approach is based on assumption that educators have the ability to analyze and solve their own instructional challenges (Glickman, 2010). The proponents of non-directive approach argue that when an individual teacher predicts the need for a change and takes the responsibility for the same, then instructional improvement is more likely to be meaningful. The supervisor in such a situation is considered only as a facilitator in providing direction to the plan. However, the behavior of the supervisor shouldn't be considered as passive where the teacher is allowed complete autonomy (Glickman, 2010). The supervisor in this approach allows the teacher to fulfill self-discovery and self-actualization. Non-directive model approach makes use of inquisitive statements to solicit opinions while encouraging the trainer to make suggestions (Copeland, 1982). According to Copeland (1982), the non-directive approach "depends more on reflecting the teacher's ideas and offering information as the teacher requests it". This approach has the objective of encouraging the teacher to assume responsibility of making as well as evaluating instructional decisions. Unlike the directive approach, the non-directive approach is premised on the idea that learning is a private experience and therefore teachers are able to conduct self-soulsearching and self-reflection and find solutions that may improve their processes of teaching and learning.

The supervision functions in an organization (school) that oversees an employee's performance in the completing task required by the employer. Educational leaders face the same dilemma as leaders of any other organization to improve the productivity of the teachers they supervise. Sergioranni, (1982) described supervision as at ritual they (supervisors and teacher) participate according to well established scripts without much consequence. Currently, the trend of supervision indicates that principals and supervisors are no longer the primary people who fulfill supervisory duties and responsibilities in the schools. Instead, department heads, and senior teachers are having significant supervisory role in their school.

For many less experienced teacher, supervision is viewed as mean less exercise that has little value than completion of the required evaluation practice form. The writer further described that "no matter how capable are designated supervisors, as long as supervision is view as doing something to the practice of teachers and for teachers. Its potential to improve schools will not be fully realized"( Sergiovanni and Starratt, 2007)

\subsection{Procedures of Classroom Observation}

The instructional supervision is a well-planned and progressive one that starts outside the classroom before the actual classroom teaching and ends outside the classroom after the observation of an actual classroom teaching. Abongo (1998) classified the instructional supervision process during teaching practice into three main phases: the pre-observation conference, the observation and the post-observation conference.

\subsubsection{The Pre-Observation Conference}

The pre-observation conference is the period that the instructional supervisor strives to develop a rapport between himself and the teacher (Abongo, 1998). The pre-observation conference involves planning the classroom observation strategy by the teacher and supervisor. During this conference teacher and supervisor together plan and discuss the kind and amount of information to be gathered during the observation period and the methods to be used to gather this information (Sergiovanni\&Starratt, 2002).

For the successfulness of classroom observation, the supervisors should have full knowledge on the activities to be carried out. In line with this, Fisher (cited in Gurnam\& Chan, 2010) suggested that to enhance the professional effectiveness of the teaching staff, administrators/supervisors must be skilled in the following area; (a) what to evaluate, (b) how to observe and analyze classroom observation and information and (c) how to translate the results of observations and the summary of data into meaningful conference feedback that guides and encourages teachers to improve instruction. She also points out that "supervision of instruction must be built on the observer"s thorough understanding and in-depth knowledge of instructional theory, not on a checklist of what should be in a lesson." During pre-observation meeting, the supervisor and teacher discuss on the lesson plan by stressing on the lesson objectives, relevance and appropriateness of content, time allocation, the availability of teaching aids, and the evaluation (ADEA, 1998). These determinations are made before the actual observation, so that both supervisor and teacher are clear about what will transpire (Glickman et al., 2004).

\subsubsection{Observation Phase}

The observation phase begins when the teacher and instructional supervisor enter the classroom. During this phase, the supervisor as a professional practitioner observes the teacher based on areas agreed up on and collects as much information as possible about the teaching and learning situation (ADEA, 1998). The supervisor also records the teacheres performance on the format of the lesson plan, the appropriateness of the lesson objectives, and the ability of teacher to provide an appropriate feedback mechanism, reinforcement, and classroom discipline. During classroom observation the supervisor is not only focuses on the recording teachers ${ }^{\text {ce }}$ performance, but also records what the students are doing. While the class observation is going on, the supervisor must follow the lesson in detail from the beginning to the end (Abongo, 1998; Gurnam\& Chan, 2010).

\subsubsection{The Post-Observation Conference}

The post-observation conference is an opportunity and setting for teacher and supervisor to exchange 
information about what was intended in a given lesson/unit and what actually happened (Sergiovanni \& Starratt, 2002). This conference helps the teacher and the supervisor to measure strengths and weaknesses and further identify any gaps when measured an ideal particularly the needs of the learners and the teachers (ADEA, 1998 ). The post-observation conference helps the teacher to improve the classroom instruction. The feedback during the post observation conference should focus on modifiable teaching behaviours. In doing this, teachers should not be asked to do things which they cannot do anything about (Abongo, 1998 :).

In general, developing the skill of observing serves a dual purpose; it helps teachers gain a better understanding of their own teaching, while at the same time refines their ability to observe, analyse and interpret, an ability that can also be used to improve their own teaching. An observation task is a focused activity to work on while observing a lesson in progress. It focuses on one or a small number of aspects of teaching or learning and requires the observer to collect data or information from the actual lesson (Ruth, 1992).

\subsection{Techniques of Instructional Supervision}

School supervisors use different systems (techniques) of supervision to activate the teaching learning process. Sergiovanni, (1995) divided these techniques in to five as clinical, collegial, individual, informal, and inquiry based supervision, he states that teachers have different need, temperaments and these needs should be recognized. Teachers are likely respond more positively to supervision when one used the better way of approach. Yet for differentiated system of supervision to work, the roles of principals and teachers will have to change teachers will have to assume the responsibility for developing the options.

\subsection{Practices of Educational Supervision in Ethiopia}

\subsubsection{Supervision at School Level}

As teaching learning process is a day-to-day and continuous process, the function of the supervision at the school level should also be a continuous responsibility. Within the school system, the supervisors are the school principal \& vice-principal, the department heads and the senior teachers. The educational programs supervision manual of Ministry of Education (MOE, 1994) has sufficiently listed the roles of supervision at the school level as follows:

\subsubsection{The Roles of School Principal in Supervision}

The school principal in his/her capacity as instructional leader, his/her responsibilities would be:

- Creating a conducive environment to facilitate supervisory activities in the school by organizing all necessary resources;

- Giving the professional assistance and guidance to teachers to enable them to realize instructional objectives; and supervise classes when and deemed necessary;

- Coordinating evaluation of teaching-learning process and the outcome through initiation of active participation of staff members and local community at large;

- Coordinating of the staff members of the school and other professional educators to review and strengthen supervisory activities and;

- Cause the evaluation of the school community relations and on the basis of evaluation results strive to improve and strengthen such relations.

\subsubsection{The Roles of Deputy Principals in Supervision}

Besides assisting the principal of the school in carrying out the above responsibilities, the school vice-principal is expected to handle the following responsibilities:

Giving over all instructional leadership to staff members;

Evaluating lesson plans of teachers and conducting the classroom supervision to ensure the application of lesson plans and; Ensuring that the curriculum of the school addresses the needs of the local community.

\subsubsection{The Roles of Department Heads in Supervision}

Because of their accumulated knowledge, skills and abilities in the particular subject as well as in the overall educational system acquired through long services /experience; the department heads have the competence to supervise educational activities. Therefore, the supervisory functions to be undertaken by the department heads are:

Coordinating the supervisory activities in their respective departments and evaluating teachers ${ }^{\text {ee }}$ performance;

Arranging on the job orientation and socialization programs to newly assigned teachers in the respective departments;

Initiating and promoting group participation in the planning, implementation and decision making of the instruction and in the evaluation of instructional outcomes;

Selecting and organizing teaching materials and making them available for use by teachers;

\subsubsection{The Roles of Senior Teachers in Supervision}

According to the career structure developed by Ministry of Education on the basis of Ethiopian Education and Training Policy of 1994, High-ranking teacher, Associate Head teacher and Head teacher are considered as 
senior teachers. Thus, such teachers because of their accumulated experience in specific subject area/areas are well positioned to supervise other teachers within their department (MoE, 1994).

\section{Method}

The descriptive survey research design was used. Descriptive survey research aims to describe behaviors and to gather people's perceptions, opinions, attitudes, and beliefs about a current issue in instructional supervision. The survey was the primary method used to gather such data or information from people. And it try to assess the status instructional supervision practice with students' academic performance. These descriptions were then summarized by reporting the number or percentage of persons reporting each response. So it described what the reality is and what actually exists within current practices and situations in the study area.

\subsection{Participants}

In Injibara Administrative Town there are seven government general primary schools which hold 271 teachers and this was the population of this study. From the general target population in Injibara Administrative Town seven government general primary schools which hold 271 teachers, five of the schools $(71.4 \%)$ were taken by using probability sampling technique especially simple random sampling (lottery system). Among the total 211 teachers (sample of the study area), $107(50.7 \%)$ of sample teachers were selected by stratified random sampling techniques system and proportionality according to the number of each school's teachers .Because this technique is better to give equal chance for all teachers. The supervisors and principals of sample schools were taken by using comprehensive sampling technique, because the number of principals and supervisors was manageable and being they were leaders in schools they expected to have more information's about the issue

\subsection{Instrumentation}

The closed ended questionnaires for instructional supervision practice survey developed by (Abebe,2014), Berhane, 2014),Bol, 2014and Netsenet, 2014) and adapted for the purpose of this study. Because these questionnaires were useful to collect data for instructional supervision practice survey which contains 27 items. Questionnaires for instructional supervision practice contain 5 likert scales (Strongly Disagree, Disagree, Undecided, Agree, Strongly Agree) for closed ended questions which were provided for teachers to assess the status of for instructional supervision practice. This was convenient to collect large amount of information from large number of respondents with in short period of time and in a relatively cost effective way. . The value of cronbach alpha was computed to check the reliability of the instruments (instructional supervision practice questionnaires) that valued 0.85 .

Interview: Interview is useful in order to get detail information from the informants about the overall present context and to assess the status of instructional supervision practice and students academic achievements or performance. Semi-structured interview questions were prepared by researcher by considering instructional supervision practice and students' academic achievements which were performed by the school principals and supervisors and which affect students' achievement or performance. The questions were open ended and provided to principals and supervisors to get detail information. And other main reason to select the semi-structured interview was because it helps to find out different persons perspectives and views deeply and to triangulate the validity of the information with the questionnaire. The procedure of interview was that, the researcher himself interviews the interviewees or the principals and supervisors.

Document Analysis: Documentary sources are one of the data collection instruments of the quantitative studies. In the case of this study also document analysis was to assess students' academic achievements. The data was taken from the school documents (rosters) of three consecutive years (2009 E.C-2011 E.C) of grade 8 regional examination average scores from schools

\section{Data Analysis}

\subsection{Instructional Supervision Practices}

The first objective of this study was to assess the status of instructional supervision in Injibara administrative town primary schools. To do this, one sample t-test was computed and the results are presented in Table 1. 
Table 1 The Status of the practice of instructional supervision in Injibara administrative town primary schools as Perceived by Teachers by Different Dimensions of the practice of instructional supervision in Injibara administrative town primary schools.

Test Value $=3$

\begin{tabular}{lllllll}
\hline \multicolumn{1}{l}{ Instructional supervision Practice Dimensions } & & & & & \\
& $\mathrm{N}$ & Mean & SD & t-test & Df & Sig \\
\hline Practice of instructional supervision & 107 & 2.1133 & .68906 & -13.311 & 106 & .000 \\
Active learning method & 107 & 2.1495 & .65479 & -13.435 & 106 & .000 \\
Class room management & 107 & 2.1533 & .74306 & -11.787 & 106 & .000 \\
Students assessment & 107 & 2.1084 & .71601 & -12.881 & 106 & .000 \\
Teachers' planning and implementing (CPD ) & 107 & 2.0911 & .75109 & -12.517 & 106 & .000 \\
Total Instructional supervision Practice & 107 & 2.1231 & .61771 & -14.684 & 106 & .000 \\
\hline
\end{tabular}

$* \mathrm{P}<0.05$

As total Instructional supervision Practice calculated mean indicated in table 1 the results of one sample ttest showed that the calculated mean score (2.12) of instructional supervision Practice was significantly lower than the expected mean which was 3. This result implies that of instructional supervision Practice of supervisors practices employed at lower level

\subsection{Students' Academic Achievement}

To know the students achievement and to relate with other independent variables the researcher taken three years (2009 E.C-2011 E.C) of ministry grade eight results of the students' achievement.

In the same way an effort was made to examine the status of students' academic achievement in Injibara administrative town primary schools. To achieve this, one sample t-test was performed and the results are presented in Table 2.

\section{Table 2 The Status of Students' Academic Achievement}

\begin{tabular}{|l|l|l|l|l|l|l|l|l|}
\hline Variable & $\mathrm{N}$ & Minimum & Maximum & Mean & SD & t-test & Df & Sig \\
\hline $\begin{array}{l}\text { Academic } \\
\text { Achievement }\end{array}$ & 171 & 36 & 82 & 53.2339 & 11.6383 & & 170 & .000 \\
\hline
\end{tabular}

$* \mathrm{P}<0.05$

As table 2 of document analysis of sample schools show that, the minimum and maximum results are 36 and 82 respectively and these scores were not frequent in the study area. .

As indicated in Table 2 the results of one sample t-test showed that the observed mean score of students' academic achievement (53.2) was significantly higher than the mean test value which was 50. This result implies that students' had above average academic achievement.

4.3 The Interrelation Between Instructional supervision Practice and Students' Academic Achievement. The next objective of the study was to examine whether there is statistically significant relationship between Instructional supervision Practice and Students' Academic Achievement in Injibara administrative town government primary schools. To achieve this purpose Pearson correlation coefficient was calculated and the results are presented in Table 3

Table 3 .Interrelation Between Instructional supervision Practice and Students' Academic Achievement.

\begin{tabular}{|l|l|l|l|l|l|l|}
\hline & Variables & $\mathrm{N}$ & Mean & $\mathrm{SD}$ & 1 & 2 \\
\hline 1 & Instructional supervision Practice & 107 & 2.1231 & .61771 & 1 & \\
\hline 2 & Academic achievement & 171 & 53.2339 & 11.6383 & -.029 & 1 \\
\hline
\end{tabular}

$* \mathrm{p}<0.05$

As indicated in Table 3 the results of correlation coefficient portrayed that there was correlation in negative direction and insignificant relationship was observed between Instructional supervision practice and students' academic achievement (-.029).

\section{Results and Discussion}

\subsection{Instructional Supervision Practices}

The first objective of this study was to assess the in status of instructional supervision practice in Injibara administrative town primary schools. To do this, one sample t-test was computed and the results are presented in Table 1.

As indicated in table 1 the results of one sample t-test showed that the reported mean score (2.11) of instructional supervision practice was significantly lower than the mean test value which was 3 . This result implies that instructional supervision practice was performed at lower level. This shows that at the study area the 
Practice of instructional supervisors were not well skill full and experienced to supervise and support the school teachers to enhance students' academic performance and run the activities of the schools as expected and intended by community and government. The findings of this study differed markedly from Onyango (2005), instructional supervision in the areas of class visitation, conferencing and teacher observation greatly influence students ${ }^{\text {ee }}$ performance.

In addition, Gachoya (2008), asserts that the supervisors who made these visits were able to have an insight into the actual state of instruction and this reinforces performance. This means that if class visits are seriously carried out, students would keep alert and study and this would influence their performance. In similar way, at table 1 the results of one sample t-test showed that the calculated mean score (2.14) of active learning method practice was significantly lower than the mean test value which was 3 . This result implies that the supervisor's supervisory practice to develop active learning method for teachers was exercised and put into operation at lower level. This indicates that at the study area the supervisors supervisory practice to develop active learning method for teachers and among staff members and there is no opportunity for staff to learn practice to develop active learning method in their actual classes.

Even though, the findings show this result the literatures suggest to the opposite of the findings as follows. For example, Chanyalew,(2005) noted that the aim of internal supervision is the improvement of the teacher, the growth of the pupil and the improvement of the teaching learning process as a whole. It refers that the internal supervisors' works in close collaboration with the teachers for bringing about improvement in teaching learning process through active learning methods.

The information obtained from interview also supports the above idea, thus one of the principals also said:

"---Well we were not conducting such formal training, but sometimes different training,

were given on different issues including implementation of active learning methods

continuous assessment and---- in school level',

As table 1 portrays the results of one sample t-test showed that the observed mean score (2.15) of instructional supervision practice to improve the class room management of teachers was significantly lower than the expected mean which was 3 . This result implies that instructional supervision practice to improve the class room management of teachers was exercised or implemented at lower level or lower than expected. In similar way this clearly indicates that instructional supervision practice at the study area did not executed to improve the class room management of teachers to manage the class well and to make the students on task on subject issues during the instruction.

Hence, concerning this issue, (Ahmed,2010) assured that classroom management to be successful teachers should follow certain principles regularly and adequately as having clear and realistic expectations, communicating with other teachers, being self-assured, always do a follow-up and understanding students role is used to minimize disruptive behavior and enhance students to their learning but the supervisors failed in implementation of techniques that can effectively handling misbehaving students. In addition to this data obtained from interview held indicated that internal supervisors were used various techniques to effectively handle misbehaving students very rarely and sometimes. What was different here is the result of the less frequent follow up by internal supervisors to effectively handle misbehaving students exposing students not to improve their behavior and the classroom practices. But in this case the finding of this research in study area differed markedly from what the literatures above suggest on the issue under this discussion.

As indicated in table 1 the results of one sample t-test showed that the reported mean score $(2.10)$ of instructional supervision practice to improve the students assessment practice was significantly lower than the mean test value which was 3 . This result implies that instructional supervision practice to improve the students assessment was exercised and done at lower level. Therefore, it is possible to conclude that, the contribution of internal supervisors in arranging short term training for teachers continues assessment improvement were at lower level in the study area .

The findings of this study differed markedly from Kimosop (2002), feedback got through interactive analysis helps both the supervisor and the teacher in terms of shared information in that, incorporation of the supervised teachers ${ }^{\text {ee }}$ suggestions helps build his confidence hence enhancing learning process. In opposite the finding of this research in study area is against what the literatures suggest. Similarly, in table 1 the results of one sample t-test showed that the calculated mean score (2.09) of instructional supervision practice to improve the teachers' planning and implementing (CPD ) practice was significantly lower than the expected mean which was 3. This result implies that practice of instructional supervision practice to improve the teachers' planning and implementing (CPD) carried out at lower level and the observed findings show that the instructional supervision practice to improve the teachers' planning and implementing (CPD) was in serious problem.

Concerning the finding of this specific dimension some literatures show opponent with the findings as follows:

According to MOE (2009), all teachers must be actively engaged in their own learning process, working with their colleagues, Identifying their own needs and the wide range of activities, formal and informal, that will 
bring about improvement of their own practice and practice of others. Additionally, this seems to be in line with that of Chrat, (2000) which was stated as "There is a need of teachers to update and improve their skills through professional development in order to cope up with rapid and ever changing environment.

Beach \& Reinhartz (2000) defined supervision as "a complex process that involves" working with teachers and other educators in a collegial, collaborative relation to enhance the quality of teaching and learning within schools and that which promotes the career long development of teachers. It is an action which renders teachers a specialized help to become more effective in teaching and promote confidence in less competent teachers.

Generally, as total Instructional supervision Practice calculated mean indicated in table 3 the results of one sample t-test showed that the calculated mean score (2.12) of Instructional supervision Practice was significantly lower than the expected mean which was 3 . This result implies that Instructional supervision Practice employed at lower level. In this case the finding of this research supported by the following literature as follows;

Ayot and Briggs (2002), opined that ineffective instructional supervision leads to poor performance among learners. He recommends regular classroom visitations to enhance higher studentse achievement level. Ngunjiri (2012), agreed with this argument that effective instructional supervision results in students getting high grades in examination while fewer supervision or lack of it lead to laxity of teachers hence poor performance. In addition, World Bank (2005) noted that, different document on the education system in Ethiopia indicate many problems school faced are linked to leadership and management. These problems including inadequate preparation and training people, poor supervision by principals and lack of commitment on the part of heads and teachers.

The above literature strengthen the findings of this study by showing that the Instructional supervision Practice in different dimensions in this study was not exercised as expected and need improvement due to different cases.

As also researcher tried to triangulate the data's in different methods to get valuable information, the open ended interview questions which are related with school Instructional supervision Practice were provided to the school supervisors. The interview responses show that more of school supervisors agreed that each dimensions of Instructional supervision practices were not performed as expected and intended due to different reasons on their schools. For example, as supervisors said "some teachers are not ready to strength their performance through supervision and collaboratively with their colleagues and also, there is lack of individual support among teachers and there are other problems to exercise the Instructional supervision practices on targeting to increase the students' achievement".

From this it was easy to understand that, the successful instructional supervision practice in the schools are very important to instructional practices, academic achievement, students' discipline, school climate and other school activities to improve the core process of the schools. But the findings of this research shows that the instructional supervision practice were not practiced as expected.

To conclude, one sample t-test show the observed mean difference between the reported and expected mean values is statistically significant. Then, the obtained mean of the total instructional supervision practice was 2.12. Here, the reported mean value (2.12) is less than the test value (3). The result in this table shows that the computed t-value - $(-14.684)$ at 106 Df has a level of significance $p=0.001$. Since the observed level of significance is lower than the acceptable $(p=0.05)$, it testifies that the observed mean difference is statistically significant. This result, therefore, implies that the participants agreed that there was no good or effective school instructional supervision practice in the primary schools of Injibara administrative town and the majority of the teachers agreed on their schools instructional supervision practice didn't practice effective schools supervisory role.

\subsection{Students' Academic Achievement}

To know the students achievement and to relate with other independent variables the researcher taken three years (2009-2011 E.C) of ministry grade eight results of the students' achievement.

In the same way an effort was made to examine the status of students' academic achievement in Injibara administrative town government primary schools. To achieve this, one sample t-test was performed and the results are presented in Table 2. As indicated in Table 2 the results of one sample t-test showed that the observed mean score of students' academic achievement (53.2) was significantly higher than the mean test value which was 50. This result implies that students' had above average academic achievement.

To maintain high levels of learner achievements, principals and supervisors need to be effective leaders and should function as instructional leaders and supervisors (Leithwood et al. 2004; Robinson et al. 2008). Students learning and achievement are affected by a combination of leadership strategies which jointly address school culture and staff development, and focus on enhancing the processes of teaching and learning (Day et al., 2000).

As the school supervisors interview responses tells that the students' academic achievement in the schools was nearest to average as school principals and supervisors responses and it strengths the document review that was analyzed in rosters of grade 8 ministry examinations results of the schools. The principals and supervisors 
during the interview also assured that the students' academic achievements in ministry exams are serious problem even though it was above average academic achievement but needs immediate solution to reduce high academic wastage. And also some principals respond that as they are working to solve the problem of academic problems by adjusting tutorial programs out of regular academic time.

5.3 The relationships between the instructional supervision Practice and Students academic performance. The next objective of the study was to examine whether there is statistically significant relationship between instructional supervision practice and students' academic performance in Injibara administrative town government primary schools. To achieve this purpose Pearson correlation coefficient was calculated and the results are presented in Table 3 .

As indicated in Table 3 the results of correlation coefficient portrayed that there was negative and statistically insignificant correlation between school instructional supervision practice and students' academic performance $\left(\mathrm{r}=-.029^{* *}, \mathrm{p}<0.05\right)$. This result implies that as in negative direction and insignificant relationship was observed between school instructional supervision practice and students' academic performance or it is in a negative direction and negative relationship was observed between school instructional supervision practice and students' academic performance. As it is indicated in the table above, the correlation analysis is expressed through Pearson correlation ( $r$ ). The results of the correlation analysis indicates that, there was a negative relationship between school instructional supervision practice and students' academic performance in the primary schools of Injibara administrative town.

Concerning the finding a lot of literature and researchers noted as follows. The primary purpose of instructional supervision is to improve teacher instruction, support teacher professional growth and development and ultimately improve student outcome. This implies that the instructional supervision practices conducted by the head teacher must have an influence on student outcome for it to be meaningful. Improving a school's instructional capacity has to improve the teaching and learning process as well as lead to student performance improvement (Sergiovanni \& Starratt, 2007). A relationship exists between instructional supervision and teacher professional development (Tesfaw \& Hofman, 2014). The influence of head teachers' instructional supervisory role indirectly influences the performance of the student outcome. The professional growth and development of the teachers through instructional supervision is what contributes to improved performance of students.

Dangara (2015) in Nigeria studies the impact that instructional supervision has on the academic achievement of students in secondary schools. The study reveals that instructional supervision practices such as inspection of teacher records keeping, checking of lesson plans and notes, classroom visitation and checking of students' notebooks has a significant correlation with student academic performance as well as teachers' performance. A significant positive relationship is established between students' academic performance and the instructional practices. The study revealed that there was a significant relationship between these activities and the academic performance of the students. This implies that failure to supervise well the teachers would result in ineffective instruction and adversely affect students' academic output.

The studied practices include moderation of marking schemes and question papers, checking punctuality of teachers and classroom attendance, classroom observation/visitation and checking students' notebooks. The study revealed that there was a significant relationship between these activities and the academic performance of the students. This implies that failure to supervise well the teachers would result in ineffective instruction and adversely affect students' academic output. Several other studies have subsequently found a significant relationship between instructional supervision and student outcome in various countries (Comfort, Aina, \& Idowu, 2017; Heaven \& Bourne, 2016; Okendu, 2012; Tyagi, 2010; Veloo, Komuji, \& Khalid, 2013). This finding can be argued to be true when other factors such as adequate levels of staffing are taken into account. However, in the Kenyan case and particularly in public schools that are characterized by inadequate teachers it becomes necessary to find out how such factors could affect instructional supervision on students' academic performance. Hence, it was necessary to conduct this study in order to find out how instructional supervision influences students' performance in the context of the challenges that the schools encounter in relation to the teachers

It is against this background that the researcher is motivated to investigate the influence of principals ${ }^{\text {ee }}$ supervision on performance of primary school students in Injibara administrative town.

According to the interviewees responses about the relations between school instructional supervision practice and students' academic performance they assured that the schools where the school instructional supervision practice was well exercised the students' academic performance achievement become high and this is unquestionable for any one. When the researcher was interviewing each sample school supervisors, two of the them said that "we are working first to exercise school instructional supervision practice as intended and as result to build positive school instructional supervision practice then, this in turn enhance students' achievements but at the moment it is difficult to achieve this mission as expected."

In general the correlation analysis is expressed through Pearson correlation (r). The result of the correlation 
analysis indicates that, there is a negative relationship between school instructional supervision practice and students achievement in the primary schools of Injibara administrative town. This indicated that there was a statistically significant relationship and has extremely low but positive relationship between instructional supervision practice and students' achievement

\section{Conclusion}

The supervisors school supervision practices and students' academic achievement was attempted to be seen in the study area. As the result of findings show that in relation to school supervision practices and students' academic achievement the study concluded that the practice (the supervisors school supervision practices and students' academic achievement ) at Injibara administrative town schools were not exercised at expected level and students' academic achievements was almost at average or expected level. Supervisors' school supervision practices and students' academic achievement were likely failing states which need urgent intervention and improvement. In addition, regarding the correlation of the two, as it has been seen in the finding, it can be concluded that there was a negative relationship and the relationship of school supervision practices and students' academic achievements were extremely low and weak. This shows that there may be different factors which highly or significantly contribute to students' academic achievement.

Generally, the findings show that as the school supervision practice fails, also the students' academic achievement but the effects on students' outcome or achievement was indirect and mediated through teachers. Also that the effect of the school supervision practice to students' academic achievement in Injibara Administrative Town government primary schools was extremely low.

\section{REFERENCES}

Abebe Tessema. (2004). The Practices and Challenges of School-Based Supervision in Government Secondary Schools of Kamashi Zone of Benshangul Gumuz Regional State. Department of Educational Planning andManagement. M.A. Thesis, Jimma University

Abongo, J. (1998). Educational management. Nairobi: Nairobi University Press

ADEA (1998).Resource materials for school inspectors. London: Chameleon Press Ltd.

Aggarwl, (1985).Theory and principles of Education: philosophical and sociological base of Education New Delhi: Vikas publishing House pvt. Ltd

Ahmed, M. (2010). Application of classroom management strategies in public and private sector at school level in Pakistan. Islamabad: Open University. International Journal of Library and Information Science

Archibong, F. I. (2010). Instructional Supervision in the Administration of Secondary Education: A Panacea for Quality Assurance. European Scientific Journal, 8(13), 61-70.

Aseltine, J. M., Faryniarz, J. O., \& Rigazio-Digilio, A. J. (2006). Supervision for Learning: A PerformanceBased Approach to Teacher Development and School Improvement. Alexandria: ASCD.

Ayot, R.M. \& Briggs, J. (2002). How Children Fail in School: Educational Research and Publications (ERAP) Nairobi, Kenya

Beach, D. M., \&Reinhartz, J. (2000).Supervisory leadership: Focus on instruction. Boston: Allyn and Bacon

BerhaneAssefa, (2014). The Practice and Challenges of Instructional Supervision I AssosaZone Primary Schools

Bernard, J. M. and Good Year, R. K. 1998. Fundamentals of Clinical Supervision (2nd ed), London: Allyn \& Bacon

Blumberg, P., \& Weimer, M. (2008). Developing Learner-Centered Teaching: A Practical Guide for Faculty. San Francisco: Jossey-Bass Publishers.

Chanyalew, Woldegebriel. (2005). The practice and problems of instructional supervision in 4secondary schools of Hadya Zone. Unpublished Masters of Arts ${ }^{e e}$ thesis, Addis Ababa University, at Addis Ababa.

Clark, P. Y. (2015). Teachers as designers in self directed learning. In A. Hargreaves and G. Fullan (Eds. Understanding teacher development. New York: Teachers College Press

Comfort, A., Aina, B. C., \& Idowu, A. F. (2017). Academic supervision as a correlate of students' academic performance in secondary schools in Ekiti State, Nigeria. International Journal of Educational Policy Research and Review, 4(1), 8-13. Copeland, W. D. (1982). Stud

Copeland, W. D. (1982). Student Teachers' Preference for Supervisory Approach. Journal of Teacher Education, $33(2), 32-36$.

Dangara, Y. U. (2015). The Impact of Instructional Supervision on Academic Performance of Secondary School Students in Nasarawa State, Nigeria. Journal of Education and Practice, 6(10), 160-167.

Day, C. Harris, A., Hadfi eld, M., Tolley, H., \& Beresford, J. (2000). Leading schools in their best achivment.

De Grauwe, A. (2007). Transforming School Supervision into a Tool for Quality Improvement. International Review of Education, 53(5/6), 709-714

ETP, 1994; Federal democratic republic government of Ethiopia education and training policy, (1994 E.C.)

Gachoya, W.A. (2008). Impact of quality assurance on education quality in secondary school in Nyeri district. 
Unpublished M.Ed Thesis, University of Nairobi.

Glanz, J. (1994). History of Educational Supervision: Proposals and Prospects. Retrieved from https://eric.ed.gov/?id=ED369178

Glickman, C. D. (2010). Supervision of instruction: A developmental approach (2nd ed). Boston: Allyn \& Bacon

Gurnam, K. S., \& Chan, Y. F. (2010).Formative supervision of teaching and learning: Issues and concerns for the school head. European Journal of Scientific Research, 39(4), 589-605.

Heaven, G., \& Bourne, P. A. (2016). Instructional Leadership and Its Effect on Students' Academic Performance. Review of Public Administration and Management. https://doi.org/10.4172/2315-7844.1000197

Ibrahim, A. S. (2013). Approaches to supervision of student teachers in one UAE teacher education program. Teaching and Teacher Education, 34(3), 38-45. https://doi.org/10.1016/j.tate.2013.04.002

Ikegbusi, N.G. \&Iheanacho, R.C. (2016). Factors militating against effective administration of secondary schools in Anambra state. World Journal of Educational Research,

Ikegbusi, N.G. (2014). Towards enhancing staff personnel management in secondary schools in Anambra state. Journal of Educational Research

Jahanian, R., \& Ebrahimi, M. (2013). Principles for Educational Supervision and Guidance. Journal of Sociological Research, 4(2), 380.

Kimosop, M.K. (2002). A Study of the role of headmaster instructional supervision in Harbarnet and Salawa division of Baringo district. Unpublished M.Ed Thesis, University of Nairobi.

Leithhood, A, K. louis, K.S. Anderson, S. and wahistrom, k. (2004) review of research, how leadership influence students learning. The Wallace Foundation

MoE (1994).Educational supervision manual. Addis Ababa: EMPDA

MoE (2002).Educational leadership and administration community participation and financial directive. Addis Ababa: EMPDA.

MoE (2010). ESDP IV Version 1 for internal discussion. Unpublished educational sector Development program document, Addis Ababa

MOE, (2009).Continuous professional development for primary and secondary school teachers, Leaders and supervisors in Ethiopia

Netsenet Kasshun, (2014). Practice and Challenges of Educational Supervision Professional Development of teachers in Government preparatory schools of Addis Ababa

Ngunjiri, J.M. (2012). Influence of head teachers instructional supervision in external examinations in public schools in Rumuruti division Kenya. Unpublished M.Ed Thesis, University of Nairobi.

Nolan, J. J., \& Hoover, L. A. (2004). Teacher supervision and evaluation: NJ: John Willey \& Sons

Nwogbo, V. N. and Okeke, B. C. (2010). Teachers' discipline and commitment to duty: A veritable instrument for academic excellence. Journal of Educational Leadership.

Ogba, F.N. \&Igu, N.C.N. (2014). Realizing quality education in Nigeria: The need to revitalize secodary education. Journal of Educational Research.

Ogbo, R.N. (2015). Effects of modified clinical supervision approach on teacher instructional performance in Ebonyi state. Journal of Educational Leadership

Okendu, J. N. (2012). The influence of instructional process and supervision on academic performance of secondary school students of Rivers State, Nigeria. Academic Research International, 3(1), 332-339.

Okumbe, J. (2006). Educational management theory and practice: The Principles and Practices of Educational Management. Nairobi: University of Nairobi Press

Olembo, J. O., Wanga, P. E., \& Karagu, N. M. (1992). Management in Education; Educational Research Publication. Nairobi: East African Educational Publishers

Onyango, O.P. (2005). The relationship between principals' management of curriculum and students' performance in Migori district. Unpublished M.Ed Thesis, University of Nairobi.

Pajak, E. (2000). Approaches to clinical supervision alternatives for improving instruction (2nd Ed) Norwood, MA: Christopher Gordon publisher PDF,March8,2006

Robinson VMJ, Lloyd CA, Rowe KJ 2008. The impact of leadership on student outcomes: An analysis of the differential effects of leadership types. Educational Administration Quarterly, 44(5): 635-674

Ruth, W. (1992). Classroom observation tasks. UK: Cambridge University Press.

Sergiovanni, (1982). To words: A theory of supervision practice: integrating the scientific, clinical, and artistic views.

Sergiovanni, T. J. (1995). The principal ship: Boston: Allyn and Beacon

Sergiovanni, T. J., and Starratt, R. J. (2007). Supervision: A redefinition (8thed.). New York: McGraw-Hill Companies Inc.

Tesfaw, T. A., \& Hofman, R. H. (2014). Relationship between instructional supervision and professional development. International Education Journal: Comparative Perspectives, 13(1), 82-99.

Tyagi, R. S. (2010). School-based instructional supervision and the effective professional development of 
teachers. Compare: A Journal of Comparative and International Education, 40(1), 111-125.

Usman, Y. D. (2015). The Impact of Instructional Supervision on Academic Performance of Secondary School Students in Nasarawa State, Nigeria. Journal of Education and Practice, 6(10), 160-167

Veloo, A., Komuji, M. M. A., \& Khalid, R. (2013). The Effects of Clinical Supervision on the Teaching Performance of Secondary School Teachers. Procedia - Social and Behavioral Sciences, 93, 35-39.

Waweru, S. N. (2004). Unpublished open learning Module. Nairobi: Kenyatta University

World Bank (2005) Recruiting and Retaining secondary school teachers and principals in Sub- Saharan Africa; Academy for Education Development, Ireand, Mynooth..

Zepeda, S. J. (2007). Instructional Supervision: Applying Tools and Concepts (2nd ed). Larchmont: Eye on Education. 